\title{
The effect of changing cow production and fitness traits on net income and greenhouse gas emissions from Australian dairy systems
}

\author{
M. J. Bell,, ${ }^{*}$ R. J. Eckard, ${ }^{*}$ M. Haile-Mariam, $† \ddagger$ and J. E. Pryce $\ddagger^{1}$ \\ ${ }^{*}$ Melbourne School of Land and Environment, University of Melbourne, Victoria 3010, Australia \\ †Biosciences Research Division, Department of Environment and Primary Industries, Agribio, 5 Ringroad, Bundoora, Victoria 3083, Australia \\ ‡Dairy Futures Cooperative Research Centre, Bundoora, Victoria 3083, Australia
}

\begin{abstract}
The aim of this study was to compare the effect of changing a range of biological traits on farm net income and greenhouse gas emissions (expressed in carbon dioxide equivalents, $\mathrm{CO}_{2}$-eq.) in the Australian dairy cow population. An average cow was modeled, using breed-average information for Holsteins and Jerseys from the Australian Dairy Herd Improvement Scheme. A Markov chain approach was used to describe the steady-state herd structure, as well as estimate the $\mathrm{CO}_{2}$-eq. emissions per cow and per kilogram of milk solids. The effects of a single unit change in herd milk volume, fat and protein yields, live weight, survival, dry matter intake, somatic cell count, and calving interval were assessed. With the traits studied, the only singleunit change that would bring about a desirable increase in both net income and reduced emissions intensity per cow and per kilogram of milk solids in Australian dairy herds would be an increase in survival and reductions in milk volume, live weight, DMI, SCC, and calving interval. The models developed can be used to assess lifetime dairy system abatement options by breeding, feeding, and management. Selective breeding and appropriate management can both improve health, fertility, and feed utilization of Australian dairy systems and reduce its environmental impact.
\end{abstract}

Key words: biological variation, methane, nitrous oxide, abatement

\section{INTRODUCTION}

Dairy production has made large advances in efficiencies over the past $60 \mathrm{yr}$ as a result of changes in breeding, nutrition, and management (Capper et al., 2009). However, losses of dietary energy in the form of methane $\left(\mathrm{CH}_{4}\right)$, as well as nitrogen $(\mathrm{N})$ in manure, are significant inefficiencies and sources of pollution in

Received October 19, 2012.

Accepted July 23, 2013.

${ }^{1}$ Corresponding author: jennie.pryce@depi.vic.gov.au the form of $\mathrm{CH}_{4}$ and nitrous oxide $\left(\mathrm{N}_{2} \mathrm{O}\right)(\mathrm{FAO}, 2010)$. Given the effect of greenhouse gas (GHG) emission levels on climate change, mitigation of these gases has gained importance in recent years.

In Australia, dairy systems are predominantly seasonal calving in the southeastern region of the country, with year-round calving in other areas (Haile-Mariam et al., 2008), and rely on pasture as an affordable source of nutrients. Supplementation of the diet with grain is carried out to optimize the achievement of the genetic potential of the cow for milk production. About $83 \%$ of cows are of Holstein genetic background and 17\% have Jersey genetic background (ADHIS, 2012).

Although diet manipulation can alter the potential production of $\mathrm{CH}_{4}$ and $\mathrm{N}_{2} \mathrm{O}$ emissions, selective breeding could offer a cost-effective means of abating emissions in the medium to long term (Moran et al., 2007). The effect of selective breeding is also permanent and cumulative. Sufficient phenotypic records of enteric $\mathrm{CH}_{4}$ emissions from dairy cows are not yet available to allow selection on this trait within national populations; however, reductions in enteric $\mathrm{CH}_{4}$ could be made through selection on DMI or residual feed intake, both of which are highly correlated with enteric $\mathrm{CH}_{4}$ emissions (de Haas et al., 2011). Genomic predictions for DMI or residual feed intake (i.e., an estimate of feed efficiency) allow their inclusion in a multiple trait selection index (de Haas et al., 2012), which takes into account the correlations between traits of interest (Pryce et al., 2009).

Production traits such as milk yield and DMI are moderately heritable in dairy cows at about 0.30 (Koenen and Veerkamp, 1998; Veerkamp, 1998) compared with low heritabilities for health and fertility traits (Pryce et al., 1999). Therefore, coupled with existing genetic variation (shown in this study), improvement is easier to achieve in DMI and milk production traits than in health and fertility. As a result, and given that production is a significant part of the selection goal, the GHG produced per unit of feed eaten are likely to reduce because of improvements in gross efficiency and a dilution of maintenance energy and protein required. Bell et al. (2011) modeled an experimental herd using a Markov 
chain approach to describe different dairy production systems. That study also assessed the effect of a phenotypic and genetic standard deviation improvement in a range of biological traits. One limitation of the study by Bell et al. (2011) was that the experimental design did not allow full expression of variation in cow survival. In the current study, we develop a more comprehensive model to assess variation in biological traits, including survival, in a national dairy population.

The loss of carbon and $\mathrm{N}$ that contribute to GHG emissions from a system can be evaluated by assessing the carbon dioxide-equivalent $\left(\mathbf{C O}_{2}\right.$-eq. $)$ emissions associated with production. The amount of $\mathrm{CO}_{2}$-eq. emissions are often expressed per animal or area and per unit product (Guinée et al., 2002). In Australia, agriculture contributes $15 \%$ ( $80 \mathrm{Mt}$ of $\mathrm{CO}_{2}$-eq.) of total emissions reported in the national inventory (DCCEE, 2012a). Agriculture is accountable for both $\mathrm{CH}_{4}$ and $\mathrm{N}_{2} \mathrm{O}$ emissions nationally, which are about 57 and $73 \%$, respectively, of the net national emissions of these GHG (DCCEE, 2012a). In 2011, the Australian Government launched a Carbon Farming Initiative whereby farmers could claim credits for reducing their net GHG emissions (DCCEE, 2012b).

The objectives of the present study were (1) to describe a dynamic dairy system that encompassed differences in genotype, nutrition, and environment, and its effect on feed intake, growth, and body composition; and (2) to assess the effect of a unit change in herd milk volume, milk fat yield, milk protein yield, live weight, survival, DMI, SCC, and calving interval on farm net income, $\mathrm{CO}_{2}$-eq. emissions per cow, and $\mathrm{CO}_{2}$-eq. emissions per kilogram of milk solids for an average Holstein herd and an average Jersey herd in Australia.

\section{MATERIALS AND METHODS}

\section{Data}

This study further developed the Australian Profit Ranking (APR) index model that derives economic values for traits of importance to the Australian dairy industry (Valentine et al., 2000; Pryce et al., 2009) to dynamically describe a milking herd that includes heifer replacements and lactating cows over a maximum of 12 lactations.

The model was constructed in Microsoft Excel (Microsoft Corp., Redmond, WA) and, in addition to changes in net income per cow, it was adapted to include $\mathrm{CO}_{2}$-eq. emissions per cow and per kilogram of milk solids caused by a management or genetic change by calculating the difference between the current state (baseline situation) and a positive or negative change in a biological trait (improved situation).

\section{Herd Structure}

The model predicts the response of a single animal and represents the mean performance of a Holstein or Jersey breed in Australia dynamically. A total of 12 lactations (referred to as age groups) were modeled, in addition to the period before replacement heifers entered the milking herd between birth and their first calving.

The number of milking herd replacements was calculated from the number of animals required to maintain the steady-state herd. Replacement animals were assumed to calve at $2 \mathrm{yr}$ of age, with cows surviving for an average of 3.0 lactations (Table 1). It was also assumed that all calf births resulted in a single live calf being born, of which half were male and half female. The only animals to leave the system were cull cows, male calves, and surplus female calves. All calves sold were assumed to leave the system immediately after birth (and contribute no GHG emissions to the system). This assumption ignores the effect of calf mortality, which was assumed to be exactly the same in both the baseline and improved situations.

The model had a steady-state herd. Although the number of cows in the model herd does not matter, for simplicity, individual cow values were multiplied by 100 to represent a herd of 100 cows. The herd structure

\begin{tabular}{|c|c|c|c|c|}
\hline Item & Unit & Average & Holstein & Jersey \\
\hline Age at first calving & $\mathrm{d}$ & 730 & 730 & 730 \\
\hline Lactations & no. & 3.0 & 2.9 & 3.0 \\
\hline Growth rate & $\mathrm{kg}$ of protein/d & 0.0033 & 0.0033 & 0.0033 \\
\hline Empty BW & $\mathrm{kg} / \mathrm{d}$ & 500 & 550 & 400 \\
\hline Mature milk volume ${ }^{1}$ & $\mathrm{~L} /$ lactation & 7,035 & 7,538 & 5,392 \\
\hline Milk protein ${ }^{1}$ & $\%$ & 3.33 & 3.27 & 3.73 \\
\hline Milk fat ${ }^{1}$ & $\%$ & 4.02 & 3.91 & 4.83 \\
\hline Gestation & $\mathrm{d}$ & 283 & 283 & 283 \\
\hline Lactation length $^{1}$ & $\mathrm{~d}$ & 324 & 328 & 307 \\
\hline
\end{tabular}

${ }^{1}$ From ADHIS (2012). 
was derived using a Markov chain approach. A Markov chain can be used to describe the herd as a vector of states(s) that cows occupy at a given point in time (Stott et al., 1999), which in this study was lactation number. See Bell et al. (2011) for a more detailed description of the approach. The vector of states at time $t$ is multiplied by a matrix of transition probabilities $(s \times s)$ to give the vector of states at time $t+1$. The probability of a cow moving on to the next lactation (from lactation $n$ to $n+1$ and from lactation 1 to $n$ ) was dependent on the chance of a cow being culled during the current lactation (Table 2). If the transition matrix is constant for all stages; that is, the model is stationary, then repeated matrix multiplication will produce a fixed long-run vector (steady-state), which is independent of the initial state vector. This long-run steady-state vector provides a useful basis for comparative assessment of alternative herd structures; that is, a change in the number of cows in each age group, as shown in Table 2. The number of milking herd replacements required to maintain the average herd structure was 33.8 , which was $0.6 \%$ more for a Holstein herd and $2.5 \%$ less for a Jersey herd (Table 2). On average, a Holstein herd had more cows in earlier lactations than a Jersey herd, where more cows tended toward more lactations.

\section{Energy Requirements, Feed Intake, and Live Weight}

It was assumed that potential energy requirements (for a milking herd replacement and milking cow) for maintenance, growth, pregnancy, activity, and lactation are achieved and that feed intake in the baseline situation will always be sufficient to achieve the animal's energy requirement, providing only that it is within the constraints of gut capacity. The constraint on intake by gut capacity was not an issue in this study based on the diet composition assumed.

Calculations of $\mathrm{ME}(\mathrm{MJ} / \mathrm{d})$ required for maintenance $\left(\mathbf{E}_{\text {maint }}\right)$, gain or loss of body protein $\left(\mathbf{E}_{\mathbf{p}}\right)$ and lipid $\left(\mathbf{E}_{\mathbf{l}}\right)$, pregnancy $\left(\mathbf{E}_{\text {preg }}\right)$, activity $\left(\mathbf{E}_{\text {act }}\right)$, and lactation $\left(\mathbf{E}_{\text {lact }}\right)$ are shown in the Appendix, and estimated values for the average herd are presented in Table 3.

The feed intake of an animal was calculated from the total ME requirement and the net energy supplied by the food consumed (Emmans, 1994, 1997):

$$
\begin{aligned}
& \text { Feed intake }(\mathrm{kg} \text { of } \mathrm{DM} / \mathrm{d})=\mathrm{E}_{\text {total }} \times 1 /\{\mathrm{ME}-0.616 \\
& \qquad \begin{array}{c}
\times\left(\mathrm{E}_{\mathrm{CH} 4} \times \mathrm{GE}\right)-[3.8 / 20 \times(\mathrm{FE} \times \mathrm{GE})] \\
-29.2 \times(\mathrm{DCP} / 6.25)\},
\end{array}
\end{aligned}
$$

where $\mathrm{ME}, \mathrm{GE}, \mathrm{FE}$, and $\mathrm{E}_{\mathrm{CH} 4}$ are the metabolizable, gross, fecal, and enteric $\mathrm{CH}_{4}$ energy (all $\mathrm{MJ} / \mathrm{kg}$ of $\mathrm{DM}$ ),

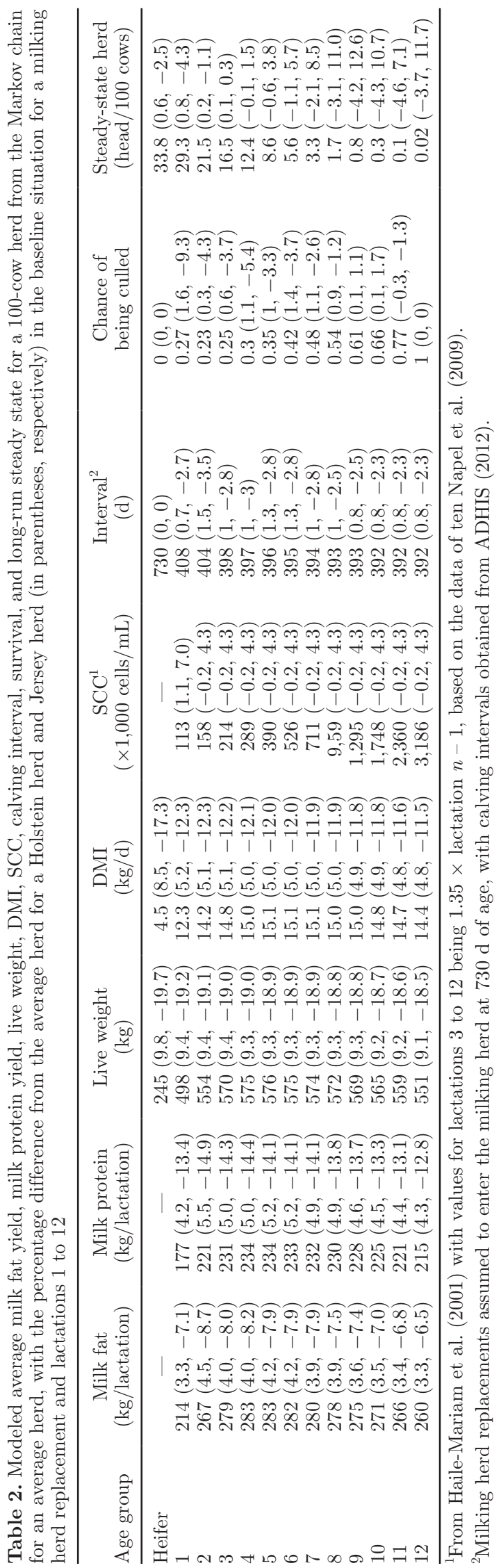


Table 3. Percentage of total energy (\% of ME) for a milking herd replacement and the average lactating dairy cow, Holstein cow, and Jersey cow required for maintenance $\left(\mathrm{E}_{\text {maint }}\right)$, protein growth $\left(\mathrm{E}_{\mathrm{p}}\right)$, lipid growth $\left(\mathrm{E}_{1}\right)$, pregnancy $\left(\mathrm{E}_{\text {preg }}\right)$, activity $\left(\mathrm{E}_{\text {act }}\right)$, and milk production $\left(\mathrm{E}_{\text {lact }}\right)$

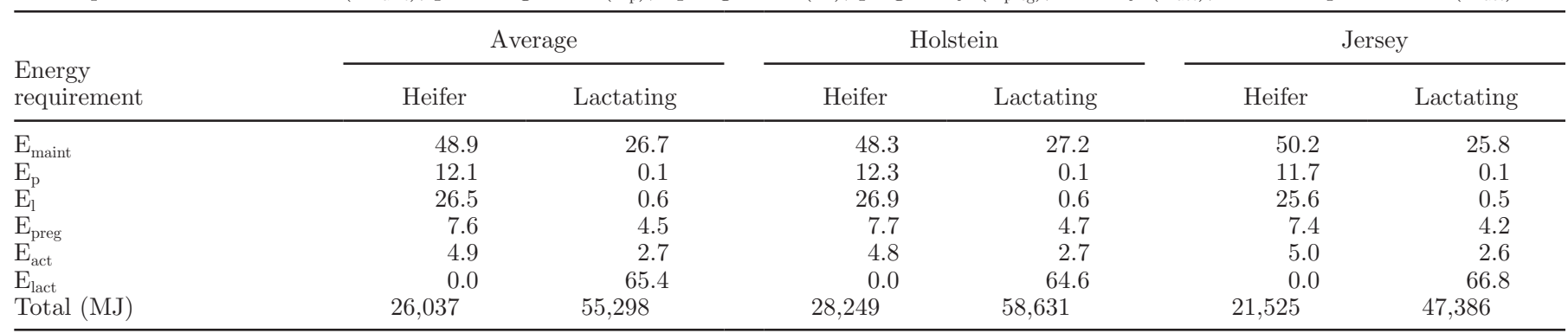

respectively. The values of 0.616 and 3.8 are the heat increments associated with fermentation and feces production, and $20 \mathrm{MJ} / \mathrm{kg}$ of $\mathrm{DM}$ was assumed to be lost in feces. The excretion of urine leads to a loss of digestible crude protein (DCP), which was estimated (DCCEE, 2012a) as

$$
\begin{gathered}
\mathrm{DCP}(\mathrm{kg} / \mathrm{kg} \mathrm{DM})=\mathrm{CP}-[(\{0.3 \times[1-(\mathrm{DMD} \\
+0.1)]\} \times \mathrm{CP})+(0.105 \times \mathrm{ME} \times 0.008)+0.0152]
\end{gathered}
$$

where $\mathrm{CP}$ is the dietary $\mathrm{CP}$ and $\mathrm{DMD}$ is the digestible $\mathrm{DM}(\mathrm{kg} / \mathrm{kg}$ of $\mathrm{DM})$. The DMD of the diet was estimated by the equation of Minson and McDonald (1987).

Because information on diet composition is not routinely collected in Australia, the diet composition was fixed. A herd replacement was assumed to be fed a diet solely of pasture, whereas the diet of a lactating cow consisted of $68 \%$ forage in the form of pasture and $32 \%$ cereal grain (Department of Primary Industries, 2012). The average chemical composition and DMD of the pasture and pasture-grain diets were obtained from an energy balance experiment using dairy cows in southeastern Australia and assumed to be 182 and 177 $\mathrm{g} / \mathrm{kg}$ of DM for CP, 520 and $120 \mathrm{~g} / \mathrm{kg}$ of DM for NDF, 10.3 and $14.4 \mathrm{MJ} / \mathrm{kg}$ for ME, 17.6 and $19.1 \mathrm{MJ} / \mathrm{kg}$ for GE, 74 and $79 \%$ for DMD, for pasture and pasturegrain diets, respectively (Williams et al., 2013). The cost of feed consumed by each age group was estimated by multiplying the total DMI by the ME content and the cost per unit ME of the diet (Table 4). A unit reduction in DMI assumed that the ME requirement of the animal remained constant in the baseline and improved situations but that total ME intake and associated cost of consumed feed was lower. Therefore, even if feed intake is sufficient, an animal that eats less will be more profitable at the same level of milk production and fitness.

The intake of NDF was used to estimate gut fill. Gut fill was assumed to equate to the water held by the fiber content $(13.2 \mathrm{~kg} / \mathrm{kg}$ of dry food; Takeda and Kiriyama, 1979) and estimated as

$$
\text { Gut fill }(\mathrm{kg} / \mathrm{d})=13.2 \times \mathrm{NDF} \text { intake }(\mathrm{kg} / \mathrm{d}) \text {. }
$$

Table 4. Assumed income and costs associated with production for an average Australian herd, Holstein herd, and Jersey herd

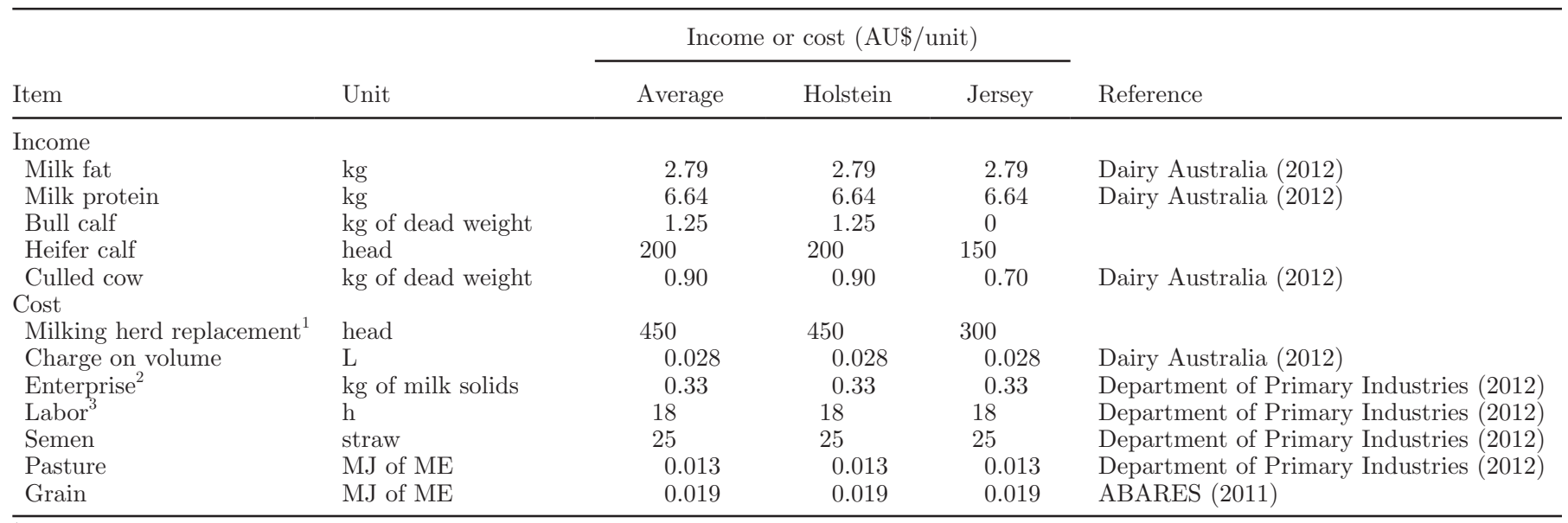

${ }^{1}$ Nonfeed cost associated with life cycle of animal.

${ }^{2}$ Herd test, animal health, shed power, and dairy supplies.

${ }^{3}$ Assumed cost of 30 min per AI and $1 \mathrm{~h}$ per incidence of clinical mastitis. 


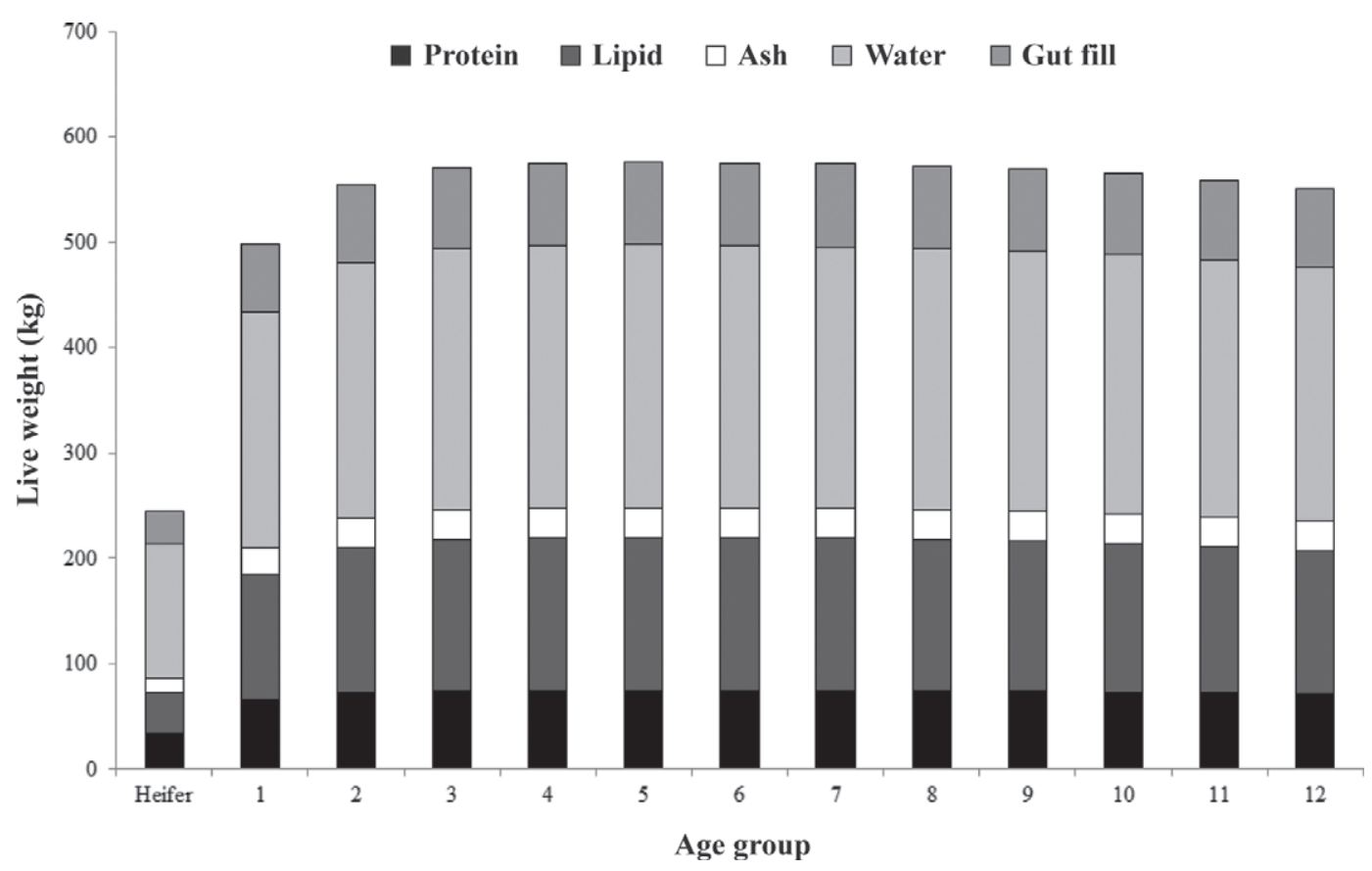

Figure 1. The average mass of protein, lipid, ash, water, and gut fill in the live weight of an average milking herd replacement and a dairy cow from lactations 1 to 12 with a mature empty BW of $500 \mathrm{~kg}$.

Gut fill is constrained by the capacity of the gut, which was estimated from Nutt et al. (1980) as $19.2 \%$ of the animal's BW. The animal's live weight was assumed to be its empty BW (kilograms of protein, lipid, water and ash; Appendix) plus gut fill. Figure 1 shows the live weight and body composition of the average cow assumed in this study with a mature empty BW of 500 $\mathrm{kg}$.

\section{Calculation of Per-Cow Lactation Yields}

Data for average number of days for each lactation, milk production at maturity, and milk composition were obtained from the Australian Dairy Herd Improvement Scheme (ADHIS, 2012) for the average Australian dairy herd, Holstein herd, and Jersey herd from the year 2010-2011 (Table 1).

The proportion of mature productivity was calculated to be $\mathrm{E}_{\text {maint }}-\left(\mathrm{E}_{\mathrm{p}}+\mathrm{E}_{\mathrm{l}}\right) /$ maximum of $\mathrm{E}_{\text {maint }}-\left(\mathrm{E}_{\mathrm{p}}+\mathrm{E}_{\mathrm{l}}\right)$ across lactations. The total amount of milk produced during each lactation was estimated by multiplying the milk production at maturity from the ADHIS data by the proportion of mature productivity for each lactation. Maturity in production of milk was reached at 4 lactations for all breeds. The amounts of milk protein, fat, and lactose produced were also calculated based on the milk fat and protein content (Table 1), and an assumed milk content of $5 \%$ lactose.

\section{GHG Emissions}

Sources of GHG emissions were from enteric and manure $\mathrm{CH}_{4}$ and direct and indirect $\mathrm{N}_{2} \mathrm{O}$ from the storage and application to land of manure (from leaching and atmospheric deposition of nitrogen from NOx and $\mathrm{NH}_{3}$ ) as attributed in the Australian National GHG Inventory for agricultural production (DCCEE, 2012a). Emissions were expressed as $\mathrm{CO}_{2}$-eq. emissions per cow and per kilogram of milk solids, the functional unit as defined by Guinée et al. (2002). The kilograms of $\mathrm{CO}_{2^{-}}$ eq. emissions for a 100-yr time horizon were calculated using conversion factors from $\mathrm{CH}_{4}$ and $\mathrm{N}_{2} \mathrm{O}$ to $\mathrm{CO}_{2}$ of 25 and 298, respectively (IPCC, 2007).

The average enteric $\mathrm{CH}_{4}$ emissions per percent of feed GE were assumed to be $7.6 \%$ for pasture fed to a milking herd replacement and $6.2 \%$ for the pasture-grain diet of a lactating cow from the study by Williams et al. (2013) in Australia. The loss of methane per percent of feed GE corresponds well with the $6.5 \pm 1 \%$ proposed by the IPCC (2006) for high to low forage diets for dairy cows. The loss of $\mathrm{CH}_{4}$ and $\mathrm{N}_{2} \mathrm{O}$ emissions were assumed to be linearly related to all biological traits except survival (a curvilinear response with increasing survival is generated by the Markov chain).

The Intergovernmental Panel on Climate Change (IPCC) Tier II methodology (IPCC, 2006) was used to predict manure $\mathrm{CH}_{4}$ and $\mathrm{N}_{2} \mathrm{O}$ emissions (from $\mathrm{N}$ 
Table 5. Assumed percentage of manure produced by management system for a milking herd replacement and lactating cow for an average system, and emission factors used to calculate greenhouse gas emissions (DCCEE, 2012a)

\begin{tabular}{|c|c|c|c|c|c|}
\hline \multirow[b]{2}{*}{ Item } & \multicolumn{2}{|c|}{ Manure produced $(\%)$} & \multirow{2}{*}{$\begin{array}{c}\text { Fraction of } \\
\text { nitrogen lost } \\
(\mathrm{N} / \mathrm{N} \text { present) }\end{array}$} & \multirow{2}{*}{$\begin{array}{c}\text { Nitrous oxide } \\
\left(\mathrm{kg} \text { of } \mathrm{N}_{2} \mathrm{O} / \mathrm{kg} \text { of } \mathrm{N}\right)\end{array}$} & \multirow{2}{*}{$\begin{array}{l}\text { Methane } \\
\text { conversion } \\
\text { factor }(\%)\end{array}$} \\
\hline & Heifer & Lactating & & & \\
\hline Anaerobic lagoon & 0 & 6 & 0.35 & 0.001 & 90 \\
\hline Liquid system & 0 & 0.5 & 0.4 & 0.001 & 65 \\
\hline Daily spread & 0 & 1.5 & 0.07 & 0 & 1 \\
\hline Grazing animal & 100 & 92 & 0.2 & 0 & 2 \\
\hline Urine & & & & 0.004 & \\
\hline Dung & & & & 0.005 & \\
\hline Leaching & & & 0.3 & 0.0125 & \\
\hline Atmospheric deposition & & & & 0.01 & \\
\hline
\end{tabular}

excretion) for manure handling systems, as well as manure deposited on pasture. The $\mathrm{N}$ excreted by the animal was partitioned into dung ( $\mathrm{N}$ intake - digested $\mathrm{N}$ intake) and urine $[\mathrm{N}$ intake $-(\mathrm{N}$ retained $+\mathrm{N}$ in dung)]. Emission factors for manure $\mathrm{CH}_{4}$ and $\mathrm{N}_{2} \mathrm{O}$ are shown in Table 5. Based on Australian GHG inventory values, the following were fixed in the calculations: $\mathrm{CH}_{4}$ conversion factor of $0.662 \mathrm{~m}^{3} / \mathrm{kg}$ of $\mathrm{CH}_{4}$, and $\mathrm{CH}_{4^{-}}$ producing capacity of manure of $0.24 \mathrm{~m}^{3} / \mathrm{kg}$ of volatile solids (DCCEE, 2012a). The volatile solids produced were calculated from the undigested OM (1 - digestible $\mathrm{OM}$ ); OM digestibility was calculated from DMD using the equation of McLeod and Minson (1974).

\section{Fertility}

All cows were assumed to be artificially inseminated. The average number of inseminations per cow was calculated as follows

$$
\begin{aligned}
& \text { No. of inseminations }=1+(\{\text { calving interval }(d) \\
& -[\text { gestation length }(d)+\text { start of estrus }(d)]\} / 21),
\end{aligned}
$$

where the start of an estrus cycle was assumed to be $426 \mathrm{~d}$ for a milking herd replacement and $82 \mathrm{~d}$ after calving for a lactating cow. The calving interval length was determined from the average lactation length plus the drying-off period length (Table 2). The gestation length was assumed to be constant at $283 \mathrm{~d}$ (Table 1 ). The cost of poor fertility was accounted for by the cost of each insemination (labor cost per $\mathrm{h} / 2+$ semen straw cost; Table 4) and the additional feed consumed and required for each extra day for a longer calving interval plus the cost per day for a replacement animal.

\section{SCC and Mastitis}

Mastitis is generally considered to be the most costly production disease in dairy cattle and for this reason it is the only health trait that is included in the APR index and consequently the only health disorder that was included in the model.

A cumulative normal distribution was used to calculate the percentage of cows in each lactation that had mastitis, with a case of mastitis being attributed to cows with a log-transformed SCC of $>400,000$ cells $/ \mathrm{mL}$ (de Haas et al., 2004). Using the average SCC $(\times 1,000$ cells/mL) for lactations 1 and 2 (Haile-Mariam et al., 2001), values for lactations 3 to 12 were scaled estimates of lactation $n-1$ by multiplying by 1.35 based on the data of ten Napel et al. (2009; Table 2). The SCC for different lactations was obtained from test-day records, which are recorded monthly with test-day milk yield. A cow infected with mastitis had an associated cost for treatment (D. Beggs, Warrnambool Veterinary Clinic, Warrnambool, VIC, Australia; personal communication) and loss of milk. Of the incidences of mastitis, 0.35 were assumed to be clinical cases and $1-0.35$ were subclinical cases. It was assumed that for a typical case of clinical mastitis, the milk was discarded for 1 wk, which was equivalent to $\mathrm{AU} \$ 46.5, \mathrm{AU} \$ 48.1$, and AU $\$ 42.7$ per treatment for an average cow, Holstein cow, and Jersey cow, respectively. Mastitis is also associated with a depression in milk yield, in accordance with the model of Valentine et al. (2000), where the proportion of total milk lost due to a clinical case during early ( 0 to $30 \mathrm{~d})$, mid (31 to $100 \mathrm{~d})$, and late (101+ d) lactation was assumed to be 0.034, 0.07, and 0.02, respectively. As the model was developed to derive economic values for a breeding selection index, it included an assumption that the reduction in milk yield would be partially captured in the animal's expressed phenotype (and therefore contributes to the animal's breeding value). It is difficult to quantify exactly what the reduction would be, but for simplicity, we assumed that the depression in yield not captured by breeding values was half the total reduction in yield. The average clinical cost of mastitis (across early, mid, and late lactation) was calculated to be $297.6 \mathrm{~L}$ and $\mathrm{AU} \$ 160.4$ 
for the average cow, 316.9 L and AU $\$ 167.2$ for a Holstein cow, and $232.0 \mathrm{~L}$ and AU $\$ 139.8$ for a Jersey cow per treatment. The average subclinical cost was $119.6 \mathrm{~L}$ and $\mathrm{AU} \$ 49.5$ for the average cow, $128.2 \mathrm{~L}$ and AU $\$ 50.3$ for a Holstein cow, and 91.7 L and AU $\$ 48.4$ for a Jersey cow per treatment. An additional $67.5 \mathrm{~L}$ and $\mathrm{AU} \$ 20.6$ for the average cow, $\mathrm{AU} \$ 20.1$ for a Holstein cow, and AU $\$ 23.9$ for a Jersey cow per treatment was added for the cost of chronic cases. The cost of a unit change in SCC was based on the cost of the incidence of mastitis within the herd.

\section{Net Income}

The model included a partial budget calculation to determine the change in income (e.g., increased income - increased costs $=$ net income) per cow in the herd for a change in a trait, which is often referred to as the economic value of the trait. The net income value corresponds to the maximum amount of money that could be made by a unit change in each trait. Variable costs and income that correspond to the traits of interest were included in the analysis in Australian dollars (Table 4). The average values for milk, feed, and livestock prices are set to align with the trend in prices for the short to medium term in Australia.

\section{Improved Efficiencies of Production}

The effect on net income, $\mathrm{CO}_{2}$-eq. emissions per cow, and $\mathrm{CO}_{2}$-eq. emissions per kilogram of milk solids by a single-unit change in 8 biological traits, representing a range of production and fitness traits, was assessed. Each trait was changed while keeping all other traits constant. The effects of single-unit increases in milk volume (L/lactation), milk fat yield, milk protein yield (both $\mathrm{kg} /$ lactation), live weight $(\mathrm{kg} / \mathrm{d})$, survival $(\% /$ lactation), DMI (representing improved feed efficiency, $\mathrm{kg} / \mathrm{d})$, SCC $(\times 1,000$ cells $/ \mathrm{mL}$ per lactation $)$, and calving interval (an indicator of fertility performance, d/ lactation) were assessed. Comparisons between the average Holstein herd and Jersey herd were made by a single unit change in each trait.

A multi-trait selection index, as described by Hayes et al. (2011), was used to assess the annual responses to selection in the 8 traits and the associated potential increased net income per cow by selective breeding. The annual response to selection on multiple traits was determined using the economic (net income) values derived for each trait in the present study. The annual response was also assessed by adjusting economic values to include income from carbon credits for the offset of GHG emissions at the current carbon price of $\mathrm{AU} \$ 23 / \mathrm{t}$ of $\mathrm{CO}_{2}$-eq. in Australia (DCCEE, 2012b). By apply- ing selection index theory, a multi-trait selection index takes into account the genetic and phenotypic correlations between traits of interest to calculate optimal index weights for each trait (Pryce et al., 2009). The software used for the selection index calculations was developed by J. van der Werf (http://www-personal. une.edu.au/ jvanderw/software.htm).

\section{RESULTS}

\section{Differences Between the Average Herd, Holstein Herd, and Jersey Herd}

Table 6 shows average production values per cow for the modeled average herd, Holstein herd, and Jersey herd. Holstein cows make up over $80 \%$ of recorded dairy cows in Australia, which has a large effect on the average herd value, with values for milk production, intake, and emissions of $\mathrm{CH}_{4}$ and $\mathrm{N}_{2} \mathrm{O}$ for an average Jersey cow being below average. Compared with a Holstein cow, a Jersey cow was associated with higher chances of survival and mastitis per lactation.

\section{Net Income}

Increasing milk protein yield by $1 \mathrm{~kg}$ per lactation, while all other traits are held constant, will increase net income by, on average, AU\$5.99 per cow in both a Holstein and Jersey herd (Table 7) compared with the baseline situation. The net income per cow for a 1-percentage-point increase in survival varied between AU $\$ 5.34$ in Jerseys and AU $\$ 6.34$ in Holsteins. Although in most cases the differences were small between breeds, increasing milk volume, live weight, DMI, SCC, and calving interval produced a negative net income. These differences probably reflected differences in production and fitness traits between Holsteins and Jerseys.

\section{Improved Efficiencies and Greenhouse Gas Emissions}

Of the total $\mathrm{CO}_{2}$-eq. emissions, the largest contribution, on average, came from enteric fermentation (77\%), followed by $\mathrm{N}_{2} \mathrm{O}(16 \%)$ and $\mathrm{CH}_{4}(7 \%)$ from manure (Table 6).

Of the 8 traits studied, a 1-unit increase in DMI resulted in the largest increase in $\mathrm{CO}_{2}$-eq. emissions per cow and per kilogram of milk solids for both Holsteins and Jerseys (Table 8). The only 1-unit change that would bring a desirable increase in both net income and reduced emissions intensity per cow and per kilogram of milk solids for both breeds would be an increase in survival and reductions in milk volume, live weight, DMI, SCC, and calving interval. Milk production traits and 
Table 6. The average (per cow) milk volume, fat yield, protein yield, live weight, survival, DMI, SCC, mastitis incidence, calving interval, N excretion, and enteric and manure $\mathrm{CH}_{4}$ and $\mathrm{N}_{2} \mathrm{O}$ emissions for a long-run steady-state average herd, average Holstein herd, and average Jersey herd

\begin{tabular}{|c|c|c|c|c|}
\hline Trait & Unit & Average & Holstein & Jersey \\
\hline Milk fat yield & $\mathrm{kg} /$ lactation & 262 & 273 & 243 \\
\hline Milk protein yield & $\mathrm{kg} /$ lactation & 217 & 228 & 188 \\
\hline Survival & $\% /$ lactation & 70.7 & 70.5 & 72.0 \\
\hline $\mathrm{DMI}^{1}$ & $\mathrm{~kg} / \mathrm{d}$ & 15.6 & 16.4 & 13.6 \\
\hline $\mathrm{SCC}$ & $\times 1,000$ cells $/ \mathrm{mL}$ per lactation & 259 & 257 & 279 \\
\hline Enteric $\mathrm{CH}_{4}{ }^{1}$ & $\mathrm{~g} / \mathrm{d}$ & 322 & 340 & 281 \\
\hline Manure $\mathrm{CH}_{4}{ }^{1}$ & $\mathrm{~g} / \mathrm{d}$ & 30 & 32 & 26 \\
\hline Manure $\mathrm{N}_{2} \mathrm{O}^{1}$ & $\mathrm{~g} / \mathrm{d}$ & 6 & 6 & 5 \\
\hline
\end{tabular}

${ }^{1}$ Includes contribution from a milking herd replacement.

${ }^{2}$ Predicted from SCC.

live weight for both breeds had similar emissions per cow and per kilogram of milk solids: a 1-unit increase in these traits resulted in an increase in emissions per cow and per kilogram of milk solids, except an increase in milk fat and protein reduced emissions per kilogram of milk solids.

The total economic annual responses to selection were AU $\$ 17.37$ and $\mathrm{AU} \$ 18.09$ for selection indexes not including and including income from carbon credits, respectively (Table 9). Selection including carbon credits would result in a reduction in selection response in production traits, most likely achieved as an indirect consequence of reducing DMI. Dry matter intake accounted for $\mathrm{AU} \$ 3.74$ (21.5\% of the response) and AU \$5.76 (31.8\%) when not including and including income from carbon credits, respectively. Therefore, selection to reduce GHG will increase annual net income by decreasing DMI.

\section{DISCUSSION}

In this research, we developed a new approach to investigating abatement options over an animal's lifetime by building on an existing model that is used to calculate economic values for the APR index. The model can be used by geneticists, researchers, and farmers to investigate different options. For the geneticist, the main aim may be to derive economic values for a selection index and calculate expected responses to selection that would arise through implementing the index. However, the model can also be used by producers to quantify profitable options that will reduce the GHG emissions per cow and per unit product of their system. Tools such as this are needed by the industry so that farmers can make informed changes that are economically viable and environmentally sustainable. This methodology could be used to underpin a carbon offset method for farmers to claim credits under the Australian Government's Carbon Farming Initiative.

This study evaluated production and fitness traits that are currently included in the APR selection index, with the addition of DMI as a proxy for feed efficiency. The economic values calculated in this study were very similar to those currently implemented by $\mathrm{AD}$ HIS through their APR selection index (www.ADHIS.

Table 7. The net income associated with a 1-unit increase in milk volume, fat yield, protein yield, live weight, survival, DMI, SCC, and calving interval for an average herd, average Holstein herd, and average Jersey herd

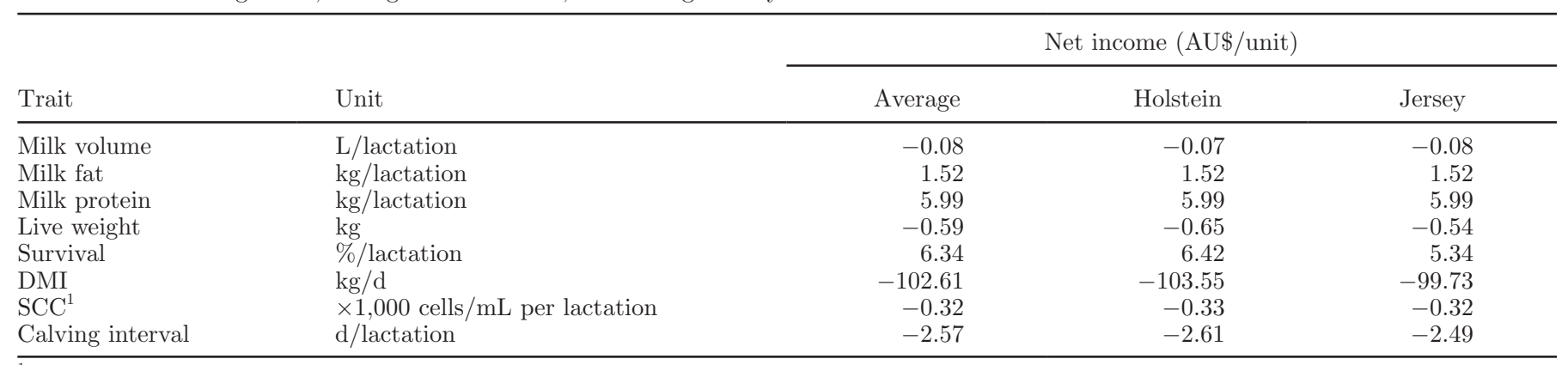

\footnotetext{
${ }^{1}$ Used to predict mastitis incidence.
} 
Table 8. The carbon dioxide ( $\mathrm{CO}_{2}$-eq.) emissions per cow and per kilogram of milk solids (MS) associated with a 1-unit increase in milk volume, fat yield, protein yield, live weight, survival, DMI, SCC, and calving interval for an average herd, average Holstein herd, and average Jersey herd

\begin{tabular}{|c|c|c|c|c|c|c|c|}
\hline \multirow[b]{2}{*}{ Trait } & \multirow[b]{2}{*}{ Unit } & \multicolumn{3}{|c|}{ Emissions (kg of $\mathrm{CO}_{2}$-eq./cow) } & \multicolumn{3}{|c|}{ Emissions (g of $\mathrm{CO}_{2}$-eq. $/ \mathrm{kg}$ of $\mathrm{MS}$ ) } \\
\hline & & Average & Holstein & Jersey & Average & Holstein & Jersey \\
\hline Milk protein & $\mathrm{kg} /$ lactation & 1.9 & 1.8 & 1.8 & -16.3 & -16.3 & -17.2 \\
\hline Live weight & $\mathrm{kg}$ & 3.4 & 3.3 & 3.8 & 7.7 & 7.7 & 8.2 \\
\hline Survival & $\% /$ lactation & -10.5 & -11.6 & -8.2 & -43.0 & -45.5 & -38.6 \\
\hline Calving interval & $\mathrm{d} /$ lactation & 5.9 & 6.4 & 5.0 & 7.5 & 7.7 & 7.2 \\
\hline
\end{tabular}

${ }^{1}$ Used to predict mastitis incidence.

com.au). Currently, DMI is not included in the APR index, so the economic value for this trait is new. The dynamic nature of the model allows additional traits to be included, such as body composition and energy or protein efficiencies.

The aim of the APR index for Australian dairy cattle is to improve the profitability of dairy farming and assign weights to milk, fat, and protein yields, live weight, daughter survival, daughter fertility, SCC (mastitis), temperament, and likeability according to their contributions to profit and their correlations (Pryce et al., 2009; Hayes et al., 2011). In fact, the derivation of economic values is the first part of the process; index weights are subsequently calculated that take full account of the genetic and phenotypic correlation structure (Pryce et al., 2009). This is important because the optimal weight for each trait in a selection index depends on its relationship to other traits. Selection index methodology can also be used to calculate responses to selection on a selection index. When deriving the economic value for SCC, it was assumed that the depression in milk yield would be partially captured in the animal's expressed phenotype, and the depression in yield not captured by breeding values was half the total reduction in yield. This assumption reduced the economic value for mastitis from $\mathrm{AU} \$ 0.41$ to $\mathrm{AU} \$ 0.32$ for the average herd by halving the depression in milk yield.

Selective breeding has been suggested as a cost-effective way to reduce GHG emissions from dairy systems (Moran et al., 2007). Hayes et al. (2011) used a multiple trait selection model to calculate the net income due to selection across the traits in the APR index. It was assumed that DMI was only available as a genomic breeding value, whereas breeding values for the other traits were available from progeny-testing, where typi-

Table 9. The expected annual response to selection for the average dairy herd from selection on a range of correlated production and fitness traits using a multi-trait selection index as described by Hayes et al. (2011)

\begin{tabular}{|c|c|c|c|c|c|c|c|c|c|}
\hline \multirow{2}{*}{ Trait } & \multirow{2}{*}{ Unit } & \multirow{2}{*}{$\begin{array}{l}\text { Phenotypic } \\
\text { SD }^{1}\end{array}$} & \multirow{2}{*}{$\begin{array}{l}\text { Genetic } \\
\mathrm{SD}^{1}\end{array}$} & \multicolumn{3}{|c|}{$\begin{array}{l}\text { Not including income } \\
\text { from carbon credits }\end{array}$} & \multicolumn{3}{|c|}{$\begin{array}{l}\text { Including income } \\
\text { from carbon credits }\end{array}$} \\
\hline & & & & $\begin{array}{c}\text { Economic } \\
\text { value (AU\$) }\end{array}$ & \multicolumn{2}{|c|}{ Annual response ${ }^{2}$} & $\begin{array}{c}\text { Economic } \\
\text { value }^{3}(\mathrm{AU} \$)\end{array}$ & \multicolumn{2}{|c|}{ Annual response ${ }^{2}$} \\
\hline Milk volume & $\mathrm{L}$ & 800 & 438 & -0.08 & 16.57 & -1.24 & -0.08 & 8.38 & -0.65 \\
\hline Milk fat & $\mathrm{kg}$ & 24 & 12 & 1.52 & 0.87 & 1.32 & 1.40 & 0.53 & 0.75 \\
\hline Survival & $\%$ & 35 & 6.6 & 6.34 & 0.78 & 4.97 & 6.58 & 0.73 & 4.83 \\
\hline DMI & $\mathrm{kg} / \mathrm{d}$ & 1.2 & 0.77 & -102.61 & -0.04 & 3.74 & -113.25 & -0.05 & 5.76 \\
\hline SCC & $\times 1,000$ cells $/ \mathrm{mL}$ & 100 & 30 & -0.32 & -0.58 & 0.19 & -0.32 & -0.48 & 0.16 \\
\hline Calving interval & $\mathrm{d}$ & 49.5 & 8.6 & -2.57 & -0.15 & 0.39 & -2.71 & -0.15 & 0.40 \\
\hline Milking speed & $\%$ & 7.2 & 2.9 & -1.74 & -0.12 & 0.22 & -1.73 & -0.12 & 0.21 \\
\hline Temperament & $\%$ & 7.5 & 3.4 & -2.69 & -0.33 & 0.87 & -2.67 & -0.30 & 0.81 \\
\hline Total & & & & & & 17.37 & & & 18.09 \\
\hline
\end{tabular}

${ }^{1}$ The phenotypic standard deviations $(\sigma p)$ of each trait were obtained from ADHIS (2012) and are estimates used in national routine genetic evaluations. The genetic standard deviation $(\sigma a)$ was derived using the formula $\sigma a=\sigma p \times h$, where $h$ is the square root of the heritability. ${ }^{2}$ Calculated based on a $0.22 \mathrm{SD}$ change in the aggregate index value (Robertson and Rendel, 1950).

${ }^{3}$ Economic values adjusted to include income from carbon credits for the offset of greenhouse gas emissions at the current carbon price of $\mathrm{AU} \$ 23 / \mathrm{t}$ of $\mathrm{CO}_{2}$-eq. in Australia (DCCEE, 2012b). 
cally phenotypes on 80 daughters for milk production traits are obtained. Using the same approach as Hayes et al. (2011) (i.e., a multi-trait selection index) and the economic values derived in this study for an average herd (Table 9; including the economic values for milking speed and temperament), the annual response to selection would be AU $\$ 17.37$ per cow. Potentially, additional income could be claimed from carbon credits for the offset of GHG emissions at the current carbon price of $\mathrm{AU} \$ 23 / \mathrm{t}$ of $\mathrm{CO}_{2}$-eq. in Australia (DCCEE, 2012b). With additional income from carbon credits, the economic value for live weight, survival, DMI, and calving interval increased, and that for milk fat, milk protein, milking speed, and temperament decreased (Table 9). Using economic values that include income from carbon credits for each trait in a multi-trait selection model would further increase the total annual economic response to selection shown in Table 9 of $\mathrm{AU} \$ 17.37$ by $4.1 \%$ ( $\mathrm{AU} \$ 18.09$ ), largely due to a lower annual economic response in milk production traits and higher annual economic response for live weight and DMI. For an average herd of 100 cows, the adjusted economic value from carbon credits would mean extra income per year of $\mathrm{AU} \$ 71.40$ per 100 cows.

The annual improvement in net income by selective breeding would appear to be more of an incentive to producers than the additional income from carbon credits and offsetting GHG emissions at the current carbon price; net farm emissions would need to be shown to reduce to meet the requirements of the Carbon Farming Initiative. Therefore, responses in each trait to selective breeding for individual farms must be quantified, which is possible using the model developed in this study.

Pryce et al. (2009) found that if the industry wanted to place a greater selection response on survival and fertility, this would reduce the optimal economic response to between 94 to $99 \%$ of its current value. In the medium to long term, selective breeding will make permanent gains in fitness traits such as survival and fertility.

Because of the low heritability of fitness traits such as survival and fertility, reductions in emissions intensity of dairy systems may be harder to achieve than selection on feed utilization or changes by other means. Some improvement in gross efficiency of dairy systems has been achieved already though selection on production (Veerkamp, 1998). A study in the UK (Jones et al., 2008) calculated that the genetic improvement in dairy cows by selecting for economic and production efficiency in the last $20 \mathrm{yr}$ had reduced $\mathrm{CH}_{4}$ and $\mathrm{N}_{2} \mathrm{O}$ emissions per unit product by 1.3 and $1.5 \%$ per year, respectively. The annual genetic response for each trait in the APR index that was used above to derive the an- nual economic response to selection for an average herd of $\mathrm{AU} \$ 17.37$ per cow (Table 9) can be used to predict future reductions in GHG emissions through selective breeding. Inserting the annual genetic response for each trait (Table 9) into the model developed in this study would reduce the GHG emissions (of $\mathrm{CH}_{4}$ and $\mathrm{N}_{2} \mathrm{O}$ ) of the average herd each year by $1.1 \%$ per unit product, which is consistent with the findings of Jones et al. (2008). This reduction in emissions intensity per unit product would support the conclusion (van de Haar and St Pierre, 2006; Chagunda et al., 2009) that animals that more energy efficient produce less waste in the form of $\mathrm{CH}_{4}$ and $\mathrm{N}$ excretion per unit product. There was estimated to be a small reduction of $0.6 \%$ in GHG emissions per cow per year in the current study. The reduction in GHG emissions of the average herd per year could be further increased to $1.2 \%$ per unit product and $0.8 \%$ per cow by the adjusted economic values with income from carbon credits. Having DMI and live weight in the selection index may have resulted in some double-counting, because live weight is a predictor of energy required for maintenance. The other source of double-counting is that the economic values for the other traits, such as milk, fat, and protein, were not corrected for DMI; again this would lead to some double-counting because feed costs are already included in estimating their economic values. However, breeding values for DMI are not currently estimated in Australia and, given the difficulty in measuring this trait, it seems likely that only genomic breeding values may at some point become available (de Haas et al., 2012). Thus, direct selection for DMI is likely to be difficult in the short to medium term and only with low accuracy. New multi-trait approaches to develop breeding values for DMI using predictors of DMI such as live weight need to be developed. Even though we have identified 2 sources of double-counting, the low accuracy of the DMI genomic breeding value means that these issues are likely to have a small effect on the results.

For both Holsteins and Jerseys, this study found that an increase in survival and a reduction in milk volume (i.e., increasing fat and protein content), live weight, DMI, SCC, and calving interval would reduce the emissions per cow and per kilogram of milk solids for both breeds. A study by Capper and Cady (2012) compared Holstein and Jersey breeds for their GHG emissions per unit of cheese production. Those authors concluded that the interaction between milk nutrient density and BW demonstrated by the Jersey population overcame the decrease in daily milk yield, thus reducing resource use and environmental impact. This finding would suggest inefficiencies in production in US Holstein herds compared with Jersey herds, which is surprising and may be more a function of the diets assumed in that 
modeling study. Given that no feed analysis information was available to go with the production data from national milk recording records in this study, the diet of a milking herd replacement was assumed to be solely pasture, and lactating cows of all breeds were fed a diet of $68 \%$ pasture and $32 \%$ cereal grain. This assumption affects the relative amounts of GHG emissions per cow and per kilogram of milk solids, which could not be compared in this study, but may explain some of conclusions of Capper and Cady (2012).

Only the quantitative traits of milk yield, milk fat and protein yields, live weight, survival, DMI, SCC, and calving interval were assessed in this study. Based on Table 8, increasing the genetic potential of a cow to produce milk increased the GHG emissions per cow because of higher feed intake. However, selection on multiple traits of which one is DMI (Table 9) could prevent an increase in emissions per cow and reduce emissions per unit product. The main benefits of selection to improve production efficiencies are (1) increased productivity and gross efficiency (i.e., the ratio of yield of milk to resource input) by diluting the maintenance cost of animals in the system, and (2) that fewer animals are required to produce the same amount of product (Capper et al., 2009; Wall et al., 2010). Currently, efficiency is captured in the APR index through the inclusion of live weight. This approximates maintenance costs, so the APR partially captures gross efficiency. However, it does not account for variation in efficiency with production level or for metabolic efficiency. The routine measurement of feed intake is costly, but genomic selection on feed intake and feed efficiency is possible (Hayes et al., 2011; de Haas et al., 2012). Selection using genomic information is especially promising for difficult or expensive-to-measure traits such as feed intake. As shown above, when genotyping of daughters is possible, significant improvements in farm income and reductions in nutrient losses are achievable.

Using genomic selection could also mean that animals could be selected on their $\mathrm{CH}_{4}$ output (de Haas et al., 2011), provided a suitable reference population was available, and increase the rate of genetic gain. Enteric fermentation is the largest source of GHG emissions from ruminant livestock systems, at over $50 \%$ of emissions (Steinfeld et al., 2006). In this study, $\mathrm{CH}_{4}$ losses contributed $84 \%$ of GHG emissions calculated. The loss of $\mathrm{CH}_{4}$ per unit product can be reduced by selecting animals on increased feed utilization efficiency or residual intake (Yan et al., 2010), without compromising productivity (Okine et al., 2003; Nkrumah et al., 2006; Hegarty et al. 2007). An assumption of this study was that all the genetic variation in GHG emissions was explained by the current breeding goal. Although selection on proxies for enteric $\mathrm{CH}_{4}$ emissions and nitrogen efficiency, such as DMI and feed efficiency, can explain a large proportion of the variation (de Haas et al., 2011), in the case of enteric $\mathrm{CH}_{4}$, considerable genetic variation exists among animals that is not explained by the model (Garnsworthy et al., 2012). The predicted reductions in GHG emissions in this study can be considered the minimum achievable based on current breeding goals. Garnsworthy et al. (2012) presented a technique that could be used to determine variation in enteric $\mathrm{CH}_{4}$ emissions among cows on commercial dairy farms to allow phenotypic and genetic components to be estimated in the future.

\section{CONCLUSIONS}

Increasing survival and reducing milk volume (i.e., increasing fat and protein content), live weight, DMI, SCC, and poor fertility in Australian dairy systems across breeds can improve the net income and reduce the GHG emissions per cow and per unit product. The greatest reductions in emissions per cow and per unit product were achievable through a unit improvement in herd DMI and survival, respectively. Being able to select animals for improved DMI efficiency will reduce system emissions per cow and per unit product, with the added benefit of farmers being able to claim carbon credits for emissions abated when net farm emissions are reduced.

\section{ACKNOWLEDGMENTS}

This work was supported by funding from Dairy Australia, Meat and Livestock Australia, and the Australian Government Department of Agriculture, Fisheries and Forestry under its Australia's Farming Future Climate Change Research Program. Research on genomic breeding values for DMI was funded by the Dairy Future's CRC and Geoffrey Gardiner Foundation. The authors thank Ian Wellock (ABN, Peterborough, UK) for guidance on animal modeling, Julius Van der Werf (University of New England, New South Wales, Australia) for the multi-trait selection index software used in this study, Ben Hayes (Department of Environment and Primary Industries, Victoria, Australia) for his comments on an earlier draft of this paper, and Peter Moate (Department of Environment and Primary Industries, Victoria, Australia) for providing information on diets.

\section{REFERENCES}

ABARES (Australian Bureau of Agricultural and Resource Economics and Sciences). 2011. Rural commodities - Coarse grains. Agricultural commodity statistics 2011, Canberra, Australia. Accessed Sep. 27, 2012. http://adl.brs.gov.au/data/warehouse/ agcstd9abcc002/agcstd9abcc0022011/ACS_2011_1.0.3.pdf. 
ADHIS (Australian Dairy Herd Improvement Scheme). 2012. National herd recording statistics 2002-2012. Accessed Mar. 10, 2012. http://www.adhis.com.au/v2/downv2.nsf/0/8b2c39cd71015148ca 257b010083d5ad?open.

AFRC (Agricultural and Food Research Council). 1993. Energy and protein requirements of ruminants: An advisory manual prepared by the AFRC Technical Committee on responses to nutrients. CABI Publishing, Wallingford, UK.

Beard, K. T. 1983. Prediction of total lactation yield in dairy cows. MS Diss. University of Melbourne, Australia.

Bell, M., E. Wall, G. Russell, G. Simm, and A. Stott. 2011. The effect of improving cow productivity, fertility, and longevity on the global warming potential of dairy systems. J. Dairy Sci. 94:3662-3678.

Capper, J. L., and R. A. Cady. 2012. A comparison of the environmental impact of Jersey compared with Holstein milk for cheese production. J. Dairy Sci. 95:165-176.

Capper, J. L., R. A. Cady, and D. E. Bauman. 2009. The environmental impact of dairy production: 1944 compared with 2007. J. Anim. Sci. 87:2160-2167.

Chagunda, M. G. G., D. A. M. Römer, and D. J. Roberts. 2009. Effect of genotype and feeding regime on enteric methane, non-milk nitrogen and performance of dairy cows during the winter feeding period. Livest. Sci. 122:323-332.

Dairy Australia. 2012. Farmgate milk price. Accessed Sep. 27, 2012. http://www.dairyaustralia.com.au/Statistics-and-markets/Prices. aspx.

DCCEE (Department of Climate Change and Energy Efficiency). 2012a. National Inventory Report 2010-Volume 1. The Australian Government Submission to the UN Framework Convention on Climate Change, Canberra, Australia.

DCCEE (Department of Climate Change and Energy Efficiency). 2012b. Carbon Farming Initiative, Canberra, ACT 2601, Australia. Accessed Sep. 25, 2012. http://www.climatechange.gov.au/cfi/.

de Haas, Y., M. P. L. Calus, R. F. Veerkamp, E. Wall, M. P. Coffey, H. D. Daetwyler, B. J. Hayes, and J. E. Pryce. 2012. Improved accuracy of genomic prediction for dry matter intake of dairy cattle from combined European and Australian data sets. J. Dairy Sci. 95:6103-6112.

de Haas, Y., R. F. Veerkamp, H. W. Barkema, Y. T. Gröhn, and Y. H. Schukken. 2004. Associations between pathogen-specific cases of clinical mastitis and somatic cell count patterns. J. Dairy Sci. $87: 95-105$.

de Haas, Y., J. J. Windig, M. P. L. Calus, J. Dijkstra, M. de Haan, A. Bannink, and R. F. Veerkamp. 2011. Genetic parameters for predicted methane production and the potential for reducing enteric emissions through genomic selection. J. Dairy Sci. 94:6122-6134.

Department of Primary Industries. 2012. Dairy industry farm monitor project annual report 2011/2012. Department of Primary Industries, Melbourne, Australia.

Emmans, G. C. 1994. Effective energy: A concept of energy utilisation applied across species. Br. J. Nutr. 71:801-821.

Emmans, G. C. 1997. A method to predict the food intake of domestic animals from birth to maturity as a function of time. J. Theor. Biol. 186:189-199.

FAO (Food and Agriculture Organization of the United Nations). 2010. Greenhouse Gas Emissions from the Dairy Sector-A Life Cycle Assessment. FAO, Rome, Italy.

France, J., J. Dijkstra, J. H. M. Thornley, and M. S. Dhanoa. 1996. A simple but flexible growth function. Growth Dev. Aging 60:71-83.

Garnsworthy, P. C., J. Craigon, J. H. Hernandez-Medrano, and N. Saunders. 2012. Variation among individual dairy cows in methane measurements made on farm during milking. J. Dairy Sci. 95:3181-3189.

Guinée, J. B., M. Gorree, R. Heijungs, G. Huppes, R. Kleijn, A. de Koning, L. van Oers, A. Wegener Sleeswijk, S. Suh, H. A. Udo de Haes, H. de Bruijn, R. van Duin, M. A. J. Huijbregts, E. Lindeijer, A. A. H. Roorda, B. L. van der Ven, and B. P. Weidema. 2002. Handbook on Life Cycle Assessment: Operational Guide to the ISO Standards. Centrum voor Milieukunde-Universiteit Leiden (CML)/Kluwer Academic Publishers, Leiden, the Netherlands.
Haile-Mariam, M., P. J. Bowman, and M. E. Goddard. 2010. Calculation of lifetime net income per year (LTNI/year) of Australian Holstein cows to validate the Australian profit ranking of their sires. 1. Genetic analyses and prediction of LTNI/year for cows still in the herd. Anim. Prod. Sci. 50:757-766.

Haile-Mariam, M., M. J. Carrick, and M. E. Goddard. 2008. Genotype by environment interaction for fertility, survival and milk production traits in Australian dairy cattle. J. Dairy Sci. 91:4840-4853.

Haile-Mariam, M., M. E. Goddard, and P. J. Bowman. 2001. Estimates of genetic parameters for daily somatic cell count of Australian dairy cattle. J. Dairy Sci. 84:1255-1264.

Hayes, B. J., J. H. J. van der Werf, and J. E. Pryce. 2011. Economic benefit of genomic selection for residual feed intake (as a measure of feed conversion efficiency) in Australian dairy cattle. Rec. Adv. Anim. Nutr. 18:31-35.

Hegarty, R. S., J. P. Goopy, R. M. Herd, and B. McCorkell. 2007. Cattle selected for lower residual feed intake have reduced daily methane production. J. Anim. Sci. 85:1479-1486.

IPCC (Intergovernmental Panel on Climate Change). 2006. 2006 IPCC guidelines for national greenhouse gas inventories. Pages 10.30-10.66 in Agriculture, Forestry and Other Land Use. Vol. 4. H. S. Eggleston, L. Buendia, K. Miwa, T. Ngara, and K. Tanabe, ed. Institute for Global Environmental Strategies (IGES), Hayama, Japan.

IPCC (Intergovernmental Panel on Climate Change). 2007. Changes in atmospheric constituents and in radiative forcing. Chapter 2 in Climate Change 2007: The Physical Science Basis. Contribution of Working Group I to the Fourth Assessment Report of the Intergovernmental Panel on Climate Change. S. Solomon, D. Qin, M. Manning, Z. Chen, M. Marquis, K. B. Avery, M. Tignor, and H. L. Miller, ed. Cambridge University Press, Cambridge, UK.

Jones, H. E., C. C. Warkup, A. Williams, and E. Audsley. 2008. The effect of genetic improvement on emission from livestock systems. Page 28 in Proc. Eur. Assoc. Anim. Prod., Vilnius, Lithuania. EAAP, Rome, Italy.

Koenen, E. P. C., and R. F. Veerkamp. 1998. Genetic covariance functions for live weight, condition score, and dry-matter intake measured at different lactation stages of Holstein Friesian heifers. Livest. Prod. Sci. 57:67-77.

Lewis, R. M., G. C. Emmans, W. S. Dingwall, and G. Simm. 2002. A description of the growth of sheep and its genetic analysis. Anim. Sci. $74: 51-62$.

McLeod, M. N., and D. J. Minson. 1974. Predicting organic matter digestibility from in vivo and in vitro determinations of dry matter digestibility. J. Br. Grassl. Soc. 29:17-21.

Minson, D. J., and C. K. McDonald. 1987. Estimating forage intake from the growth of beef cattle. Trop. Grassl. 21:116-122.

Moran, D., A. Barnes, and A. McVittie. 2007. The rationale for Defra investment in $R \& D$ underpinning the genetic improvement of crops and animals (IF0101). Final report to Defra. Defra, London, UK.

Nkrumah, J. D., E. K. Okine, G. W. Mathison, K. Schmid, C. Li, J. A. Basarab, M. A. Price, Z. Wang, and S. S. Moore. 2006. Relationships of feedlot feed efficiency, performance, and feeding behavior with metabolic rate, methane production, and energy partitioning in beef cattle. J. Anim. Sci. 84:145-153.

Nutt, B. G., J. W. Holloway, and W. T. Butts Jr. 1980. Relationship of rumen capacity of mature Angus cows to body measurements, animal performance and forage consumption on pasture. J. Anim. Sci. $51: 1168-1176$.

Okine, E. K., J. A. Basarab, L. A. Goonewardene, P. Mir, Z. Mir, M. A. Price, P. F. Arthur, and S. S. Moore. 2003. Residual feed intake-What is it and how does it differ from traditional concepts of feed utilization. Pages 10-13 in Proc. CSAS Annu. Mtg., Saskatoon, Saskatchewan, Canada. Canadian Soc. Anim. Sci. (CSAS), Ottawa, ON, Canada.

Parks, J. R. 1982. A Theory of Feeding and Growth of Animals. Springer-Verlag, Berlin, Germany.

Pryce, J. E., B. L. Nielson, R. F. Veerkamp, and G. Simm. 1999. Genotype and feeding system effects and interactions for health and fertility traits in dairy cattle. Livest. Prod. Sci. 57:193-201. 
Pryce, J. E., J. H. J. van der Werf, M. Haile-Mariam, B. Malcolm, and M. E. Goddard. 2009. Updated index weights for the Australian Profit Ranking in dairy. Proc. Assoc. Advmt. Anim. Breed. Genet. 18:143-146.

Reid, J. T., G. H. Wellington, and H. O. Dunn. 1955. Some relationships among the major chemical components of the bovine body and their application to nutritional investigations. J. Dairy Sci. 38:1344-1359.

Robertson, A., and J. M. Rendel. 1950. The use of progeny testing with artificial insemination with dairy cattle. J. Genet. 50:21-31.

Steinfeld, H., P. Gerber, T. Wassenaar, V. Castel, M. Rosales, and C. de Haan. 2006. Livestock's long shadow: Environmental issues and options. Food and Agriculture Organization of the United Nations, Rome, Italy.

Stott, A. W., R. F. Veerkamp, and T. R. Wassell. 1999. The economics of fertility in the dairy herd. Anim. Sci. 68:49-57.

Takeda, H., and S. Kiriyama. 1979. Correlation between the physical properties of dietary fibers and their protective activity against amaranth toxicity in rats. J. Nutr. 109:388-396.

ten Napel, J., Y. de Haas, G. de Jong, T. J. G. M. Lam, W. Ouweltjes, and J. J. Windig. 2009. Characterization of distributions of somatic cell counts. J. Dairy Sci. 92:1253-1264.

Valentine, H., L. Jones, K. T. Beard, and R. Poole. 2000. The development of a total merit index for genetic selection of Australian dairy cattle. Australian Dairy Herd Improvement Scheme, Victoria, Australia.

VandeHaar, M. J., and N. St Pierre. 2006. Major advances in nutrition: Relevance to the sustainability of the dairy industry. J. Dairy Sci. 89:1280-1291.

Veerkamp, R. F. 1998. Selection for economic efficiency of dairy cattle using information on live weight and feed intake: A review. J. Dairy Sci. 81:1109-1119.

Visscher, P., M. Goddard, and P. Bowman. 1994. Breeding objectives for pasture based dairy production systems. Livest. Prod. Sci. 40:123-137.

Wall, E., G. Simm, and D. Moran. 2010. Developing breeding schemes to assist mitigation of greenhouse gas emissions. Animal 4:366376.

Wellock, I. J., G. C. Emmans, and I. Kyriazakis. 2003. Modelling the effects of thermal environment and dietary composition on pig performance: Model logic and concepts. Anim. Sci. 77:255-266.

Williams, S. R. O., T. Clarke, M. C. Hannah, L. C. Marett, P. J. Moate, M. J. Auldist, and W. J. Wales. 2013. Energy partitioning in herbage-fed dairy cows offered supplementary grain during an extended lactation. J. Dairy Sci. 96:484-494.

Yan, T., C. S. Mayne, F. G. Gordon, M. G. Porter, R. E. Agnew, D. C. Patterson, C. P. Ferris, and D. J. Kilpatrick. 2010. Mitigation of enteric methane emissions through improving efficiency of energy utilization and productivity in lactating dairy cows. J. Dairy Sci. 93:2630-2638.

\section{APPENDIX}

\section{Energy Requirements for Growth and Maintenance}

Several equations have been proposed to describe growth (Parks, 1982; France et al., 1996). When conditions are suitable for growth to meet its potential, the Gompertz function has been shown to be an adequate predictor (Emmans, 1997). Lewis et al. (2002) showed that the Gompertz function has the desired properties of growth where (1) weight tends to a final or asymptotic value with time, (2) growth rate has a maximum at some intermediate weight, and (3) the relative growth rate decreases as weight increases toward maturity. The growth curve used to determine the potential protein
(P) mass from conception to maturity (Emmans, 1997; Lewis et al., 2002) was

$$
\mathrm{P}(\mathrm{kg} / \mathrm{d})=\mathrm{P}_{\mathrm{m}} \times \exp \{-\exp [\mathrm{G}-(\mathrm{B} \times \mathrm{t})]\},
$$

where $\mathrm{P}_{\mathrm{m}}$ is protein mass $(\mathrm{kg})$ at maturity, $\mathrm{G}$ is the Gompertz coefficient, B is the growth rate (Table 1), and $t$ is the time in days from conception. The degree of maturity is described by $\exp \{-\exp [\mathrm{G}-(\mathrm{B} \times \mathrm{t})]\}$. The parameter values $\mathrm{G}$ and $\mathrm{B}$ were adjusted so the animal was $8 \%$ of its mature BW at birth (Beard, 1983) and $76 \%$ of its mature productivity at lactation 1 (HaileMariam et al., 2010). Based on ADHIS (2012) data, we assumed no difference between breeds in their degree of mature productivity at lactation 1 . Coefficient $\mathrm{G}$ was set at 2 and B at 0.0033 for all animals. The sigmoid Gompertz curve assumes that growth will reach a peak at approximately 0.368 of the animal's mature weight and will then decline to zero at maturity. After maturity of protein mass, the animal's protein mass declined at a rate of $1 \%$ of mature mass per lactation (Beard, 1983), which was described by a "switch-off" function as

$$
\mathrm{P}_{\text {off }}=\mathrm{P} \times\left[\mathrm{k}^{\mathrm{n}} /\left(\mathrm{t}^{\mathrm{n}}+\mathrm{k}^{\mathrm{n}}\right)\right]
$$

where $\mathrm{P}_{\text {off }}$ is the new scaled protein mass after maturity is reached, and $\mathrm{k}$ and $\mathrm{n}$ were 10,000 and 5, respectively. The other body components of lipid (L), water (W), and ash (A) were estimated from $\mathrm{P}$ using the following equations (Wellock et al., 2003):

$$
\begin{gathered}
\mathrm{L}=\mathrm{L}_{\mathrm{m}} \times \mathrm{P}^{\mathrm{b}} / \mathrm{P}_{\mathrm{m}}{ }^{\mathrm{b}}, \\
\mathrm{W}=\left(\mathrm{W}_{\mathrm{m}} / \mathrm{P}_{\mathrm{m}} \times \mathrm{P}_{\mathrm{m}}{ }^{1-0.885}\right) \times \mathrm{P}^{0.885}, \\
\text { and } \mathrm{A}=\mathrm{A}_{\mathrm{m}} / \mathrm{P}_{\mathrm{m}} \times \mathrm{P}^{1},
\end{gathered}
$$

where $\mathrm{L}_{\mathrm{m}}, \mathrm{W}_{\mathrm{m}}$, and $\mathrm{A}_{\mathrm{m}}$ are lipid, water, and ash mass $(\mathrm{kg})$ at maturity, and $\mathrm{b}$ is $1.46 \times\left(\mathrm{L}_{\mathrm{m}} / \mathrm{P}_{\mathrm{m}}\right)^{0.23}$. The fraction of mature empty $\mathrm{BW}$ for $\mathrm{P}_{\mathrm{m}}, \mathrm{L}_{\mathrm{m}}, \mathrm{W}_{\mathrm{m}}$, and $\mathrm{A}_{\mathrm{m}}$ was set at $0.15,0.29,0.50$, and 0.06 (Reid et al., 1955) for all animals. The rates of protein and lipid growth (kg/d; Emmans, 1997) were

$$
\begin{gathered}
\mathrm{dP} / \mathrm{dt}=\mathrm{P} \times \mathrm{B} \times \ln \left(\mathrm{P}_{\mathrm{m}} / \mathrm{P}\right), \\
\text { and } \mathrm{dL} / \mathrm{dt}=\mathrm{L} \times \mathrm{B} \times \ln \left(\mathrm{L}_{\mathrm{m}} / \mathrm{L}\right) .
\end{gathered}
$$

The energy requirement for maintenance is defined as that needed to maintain zero rates of retention of both protein and lipid. The $\mathrm{E}_{\text {act }}(\mathrm{MJ} / \mathrm{d})$ was estimated as a fixed proportion of $\mathrm{E}_{\text {maint }}$ at 0.10 . The $\mathrm{E}_{\text {maint }}$ was estimated (Emmans, 1997) as 


$$
\mathrm{E}_{\text {maint }}(\mathrm{MJ} / \mathrm{d})=1.63 \times \mathrm{P} / \mathrm{P}_{\mathrm{m}} 0 \cdot 27 \text {. }
$$

The energy required for a gain in protein mass was calculated from Emmans (1994) as (23.6 - 5.63) + $(35.5-0.16 \times 29.2)=48.8 \mathrm{MJ} / \mathrm{kg}$ and loss as $(23.6$ $-5.63-0.16 \times 29.2)=13.3 \mathrm{MJ} / \mathrm{kg}$, where $23.6 \mathrm{MJ} /$ $\mathrm{kg}$ is the heat of combustion of protein, and 5.63, 35.5, and $29.2 \mathrm{MJ} / \mathrm{kg}$ are net energy losses associated with protein catabolism, protein retention, and nitrogen loss in urine respectively. The energy required for a gain in lipid mass was estimated also from Emmans (1994) as $39.3 / 0.70=56.1 \mathrm{MJ} / \mathrm{kg}$ and loss as $39.3 \mathrm{MJ} / \mathrm{kg}$, where 39.3 is the heat of combustion of lipid and 0.70 is the efficiency of lipid retention.

Therefore, the energy $(\mathrm{MJ} / \mathrm{d})$ for $\mathrm{E}_{\mathrm{p}}$ and $\mathrm{E}_{\mathrm{l}}$ were calculated by multiplying $\mathrm{dP} / \mathrm{dt}$ and $\mathrm{dL} / \mathrm{dt}$ by the energy cost of protein or lipid body composition change as defined above.

Thus, for a gain in protein or lipid, $\mathrm{E}_{\mathrm{p}}$ and $\mathrm{E}_{\mathrm{l}}$ are as follows:

$$
\begin{gathered}
\mathrm{E}_{\mathrm{p}}(\mathrm{MJ} / \mathrm{d})=48.8 \times \mathrm{dP} / \mathrm{dt}, \\
\text { and } \mathrm{E}_{1}(\mathrm{MJ} / \mathrm{d})=56.1 \times \mathrm{dL} / \mathrm{dt},
\end{gathered}
$$

whereas equations for a loss in protein or lipid, $\mathrm{E}_{\mathrm{p}}$ and $\mathrm{E}_{1}$ are

$$
\begin{gathered}
\mathrm{E}_{\mathrm{p}}(\mathrm{MJ} / \mathrm{d})=13.3 \times \mathrm{dP} / \mathrm{dt}, \\
\text { and } \mathrm{E}_{\mathrm{l}}(\mathrm{MJ} / \mathrm{d})=39.3 \times \mathrm{dL} / \mathrm{dt} .
\end{gathered}
$$

\section{Energy Requirements for Pregnancy} lows:

The value for $\mathrm{E}_{\mathrm{preg}}$ was defined (AFRC, 1993) as fol-

$$
\begin{aligned}
& \mathrm{E}_{\text {preg }}(\mathrm{MJ} / \mathrm{d})= \\
& {\left[\left(10^{\{151.665-151.64 \times \exp [-0.0000576 \times \text { gestation length }}\right.\right.} \\
& (\text { days })]\}) / 0.13 / 36.2] \times \text { calflwgt }(\mathrm{kg}),
\end{aligned}
$$

where 0.13 is the efficiency of pregnancy, $36.2 \mathrm{MJ} / \mathrm{kg}$ is the energy required for growth, and calflwgt is the empty BW at birth of the calf. The empty BW of the calf was calculated as the average empty BW of the dam (which increased with parity) multiplied by the weight adjustment factor at $1 \mathrm{~d}$ of age, which was set at $8 \%$ of mature empty BW.

\section{Energy Requirements for Lactation}

The energy for lactation $\mathrm{E}_{\text {lact }}$ was calculated as

$$
\begin{gathered}
\mathrm{E}_{\text {lact }}(\mathrm{MJ} / \mathrm{d})=35.6 \times \text { milk protein yield }+69.9 \\
\times \text { milk fat yield }+25.1 \times \text { milk lactose yield }
\end{gathered}
$$

where $35.6,69.9$, and $25.1 \mathrm{MJ} / \mathrm{kg}$ are the energy requirements to produce $1 \mathrm{~kg}$ of milk protein, fat, and lactose, respectively (Visscher et al., 1994).

\section{Total Energy Requirements}

The total ME requirement of a cow was simply

$$
\mathrm{E}_{\text {total }}(\mathrm{MJ} / \mathrm{d})=\mathrm{E}_{\text {maint }}+\mathrm{E}_{\mathrm{p}}+\mathrm{E}_{\mathrm{l}}+\mathrm{E}_{\text {act }}+\mathrm{E}_{\text {preg }}+\mathrm{E}_{\text {lact. }} \text {. }
$$

